\title{
IMPLEMENTASI ALGORITMA NÄ̈VE BAYES CLASSIFIER UNTUK ANALISIS SENTIMEN CUSTOMER PADA TOKO ONLINE
}

\author{
PRIMA DINA ATIKA \\ Teknik Informatika, Fakultas Teknik Universitas Bhayangkara Jakarta Raya \\ Jl. Raya Perjuangan, Marga Mulya, Bekasi Utara, Marga Mulya, Bekasi Utara, \\ Kota Bekasi, Jawa Barat 17121 (021) 88955882

\section{SUHADI} \\ STMIK Bani Saleh \\ Jalan Madmuin Hasibuan No.68, Bekasi Timur, Kota Bekasi-Jawa Barat \\ Email: prima.dina@dsn.ubharajaya.ac.id, hadims71ndl@gmai.com
}

\begin{abstract}
Online Shopping or commonly known as Online Shop is a place to buy goods and services through the Internet, or in the form of electronic commerce (E-commerce) used for seller-to-seller or seller-to-consumer transactions through an application that the transactions are carried out without mediate services. From several online stores in Indonesia, it shows that the market is very significant, so that it is favored by the people of Indonesia. In this study, an analysis will be conducted to see customer sentiment in shopping at online stores using the Nä̈ve Bayes Classifier algorithm. The Naive Bayes Classifier algorithm is a classification method using probability and statistical methods. In this study, consumers are addressed to the segment of students, college students and the general public. The results of customer sentiment analysis research for Online stores $A, B, C, D, E$ are for Price Variable (VH) of 0.00000023, Product Variable (VP) of 0.0000049, Transaction Ease Variable (VKT of 0.0000048 , Transaction Security Variable (VKMT) of equal to 0.0000038, Trust Variable (VK) of 0.000015.
\end{abstract}

Key words: Online Stores, Customer Sentiments, E-Commerce, Naive Bayes Classifier (NBC)

Abstrak - Belanja Online atau biasa dikenal dengan Toko Online atau Online Shop merupakan tempat pembelian barang dan jasa melalui media Internet, atau salah satu bentuk perdagangan elektronik (Ecommerce) yang digunakan untuk kegiatan transaksi penjual ke penjual ataupun penjual ke konsumen melalui sebuah aplikasi dan transaksi dilakukan tanpa layanan perantara. Dari beberapa toko online yang ada di Indonesia menunjukkan bahwa marketnya sangat signifikan, sehingga digemari oleh masyarakat Indonesia. Dalam penelitian ini akan dilakukan analisis untuk melihat sentimen customer dalam belanja di toko Online dengan menggunakan metode algoritma nä̈ve bayes Classifier, Algoritma Naive Bayes Classifier merupakan metode klasifikasi menggunakan metode probabilitas dan statistik. Dalam penelitian ini konsumen ditujukan kepada segmen pelajar, mahasiswa dan masyarakat umum. Hasil penelitian analisis sentimen customer untuk toko Online A, B, C, D, E adalah Untuk Variabel Harga (VH) sebesar 0.00000023, Variabel Produk (VP) sebesar 0.0000049, Variabel Kemudahan Transaksi (VKT sebesar 0.0000048, Variabel Keamanan Transaksi (VKMT) sebesar 0.0000038 , Variabel Kepercayaan (VK) sebesar 0.000015 .

Kata Kunci: Toko Online, Sentimen Customer, E-Commerce, Naive Bayes Classifier (NBC)

\section{PENDAHULUAN}

Dalam era digital ini, penggunaan internet sudah menjadi bagian gaya hidup masyarakat untuk melakukan apapun yang diinginkan. Dalam perkembangannya, internet bukan hanya digunakan sebagai media informasi dan media komunikasi saja, namun juga dapat menambah pendapatan bagi seseorang dalam melakukan transaksi, seperti sekarang ini orang-orang menyukai semua hal yang berbau praktis dan otomatis untuk menjalankan kelangsungan menjalankan transaksi jual-beli. Belanja online atau yang disebut dengan Toko Online kerap mewarnai perdagangan dunia maya, merupakan tempat pembelian barang dan jasa melalui 
media Internet, atau salah satu bentuk perdagangan elektronik (Ecommerce) yang digunakan untuk kegiatan transaksi penjual ke penjual ataupun penjual ke konsumen melalui sebuah aplikasi dan transaksi dilakukan tanpa layanan perantara.

Saat ini, di Indonesia jumlah pengunjung shopping Online bias mencapai 73\% perharinya, dengan masing-masing konsumen $65 \%$ wanita dan $35 \%$ pria ("Find Out Ecommerce Competition in Indonesia," 2019). Toko Online terbaik di Indonesia yang terdiri dari toko online A, B, C, D, E dan Toko Online D memimpin seluruh Marketplace dengan 137.200.900 orang pengunjung, toko online $\mathrm{C}$ dengan pengunjung 115.256.600 orang, toko online B dengan pengunjung 74.995.300 orang, toko online A dengan pengunjung 52.044.500 orang, dan toko online E dengan pengunjung 10.656 .900 orang. Dampak lain dari penggunaan Internet yaitu penggunaan media sosial yang terus meningkat ("Digital in 2019," 2019) dari total populasi Indonesia sebanyak 265,4 juta jiwa, pengguna aktif media sosialnya mencapai 130 juta dengan penetrasi $49 \%$. Banyak pengguna yang senang memainkan media sosial dan menjadikan media sosial sarana untuk menuangkan opininya dan membahas berbagai masalah yang ada di sekitar, opini dan masalah tersebut dapat diolah menjadi suatu informasi dengan suatu cara yaitu analisis sentimen. Analisis sentimen merupakan suatu aktivitas menganalisis suatu perasaan, emosi dan opini seseorang yang di ekspresikan dalam teks untuk dkelompokkan yang terbagi menjadi sentimen positif dan negatif.

Dalam penelitian ini literatur yang digunakan adalah dari beberapa jurnal adalah sebagai berikut, penelitian yang dilakukan oleh (Nurhuda, Widya Sihwi, \& Doewes, 2016) Kesimpulan penelitian ini adalah data yang berupa opini masyarakat dari twitter kemudian diklasifikasi menggunakan metode Nä̈ve Bayes. Hasil yang didapatkan dari pengujian 100 data random yang sudah diklasifikasi polaritas secara manual dengan menggunakan 1.400 data training mendapatkan akurasi sebesar $90 \%$.

Penelitian yang dilakukan oleh (Setyawan \& Winarko, 2016). Kesimpulan dari jurnal adalah Hasil akurasi yang didapatkan dalam penelitian ini adalah $81.76 \%$ dengan nilai recall dan precisionnya masing-masing adalah 0.63 dan 0.72 dengan pengumpulan data dilakukan web scraping yaitu dengan mengumpulkan review opini masyarakat di web target.

Penelitian yang dilakukan oleh (Wan \& Gao, 2015). Kesimpulan dari jurnal adalah Metode The Ensemble Classifier yaitu metode yang menggabungkan 5 metode sekaligus (Naïve Bayes, Bayesian Network, SVM, C4.5 dan Random Forest) memperoleh akurasi tertinggi yaitu sebesar 91.7\%, metode Lexicon-based Classifier memperoleh akurasi paling rendah yaitu sebesar $67.9 \%$ saja. Untuk tingkat akurasi metode lainnya yaitu Naïve Bayes sebesar 90\%, Bayesian Network sebesar 91.4\%, SVM sebesar 84.6\% C4.5 sebesar 86\% dan Random Forest sebesar $89.8 \%$ perolehan akurasi tersebut berdasarkan dataset yang menggunakan dua kelas (kelas positif dan negative) sedangkan perolehan akurasi untuk dataset yang menggunakan tiga kelas (ditambahkan kelas netral) sama saja urutannya tetapi nilai akurasi pada masing-masing metode sedikit menurun.

\section{METODE}

Dalam penelitian ini teknik pengumpulan data (Sugiyono, 2014) digunakan adalah dengan menggunakan kuesioner dari Google Form, data yang diperoleh dari responden sebanyak 350 (tiga ratus lima puluh) rentang waktu (satu) bulan, sampel yang di ambil berdasarkan opini customer toko online, dalam form survei dicantumkan beberapa atribut dari masing-masing variabel yang akan dianalisis daftar pertanyaan adalah (a) Varibel Harga (VH) (b) Variabel Produk (VP), (c) Variabel Kemudahan Transaksi (VKT), (d) Variabel Keamanan Transaksi (VKMT) dan (e) Variabel Kepercayaan (VK) dengan uraian pertanyaan responden sebagai berikut:

Tabel 1. Deskripsi Daftar Pertanyaan Responden Untuk Variabel Harga (VH) 


\begin{tabular}{|c|l|}
\hline Kode & \multicolumn{1}{|c|}{ Deskripsi Pertanyaan Responden } \\
\hline VH1 & $\begin{array}{l}\text { Katalog harga produk jelas ditampilkan dan dimengerti } \\
\text { konsumen (Daftar Harga) }\end{array}$ \\
\hline VH2 & $\begin{array}{l}\text { Potongan harga yang diberikan toko Online mempengaruhi } \\
\text { minat beli konsumen untuk belanja secara Online (Diskon) }\end{array}$ \\
\hline VH3 & $\begin{array}{l}\text { Banyaknya promosi yang dilakukan oleh toko Online seperti } \\
\text { potongan harga pada hari tertentu, beli 1 gratis 1, cuci gudang } \\
\text { dan lainnya menjadi daya tarik untuk berbelanja secara Online }\end{array}$ \\
\hline VH4 & Harga produk toko Online lebih murah \\
\hline VH5 & Konsumen sangat mudah melakukan perbandingan harga \\
\hline VH6 & $\begin{array}{l}\text { Konsumen dapat menyesuaikan pilihan harga dengan } \\
\text { pendapatan masing-masing }\end{array}$ \\
\hline
\end{tabular}

Tabel 2. Deskripsi Daftar Pertanyaan Responden Untuk Variabel Produk (VP)

\begin{tabular}{|c|l|}
\hline Kode & \multicolumn{1}{|c|}{ Deskripsi Pertanyaan Responden } \\
\hline VP1 & $\begin{array}{l}\text { Banyaknya pilihan yang dijual toko Online sehingga } \\
\text { memudahkan konsumen dalam mencari produk yg di inginkan }\end{array}$ \\
\hline VP2 & Produk yg dijual toko Online memiliki kualitas yang lebih baik \\
\hline VP3 & $\begin{array}{l}\text { Toko Online Memberikan pelayanan tambahan untuk } \\
\text { menghindari kerusakan ketika pengiriman yaitu memberikan } \\
\text { kemasan tambahan pada setiap produk yang dibeli }\end{array}$ \\
\hline VP4 & Merek produk apapun bisa didapatkan dengan belanja Online \\
\hline
\end{tabular}

Tabel 3. Deskripsi Daftar Pertanyaan Responden Untuk Variabel Kemudahan Transaksi (VKT)

\begin{tabular}{|c|l|}
\hline Kode & \multicolumn{1}{|c|}{ Deskripsi Pertanyaan Responden } \\
\hline VKT1 & Memiliki respon yang cepat ketika melayani pembeli \\
\hline VKT2 & $\begin{array}{l}\text { Toko Online selalu menerima pesanan produk dari konsumen } \\
\text { selama 24 jam }\end{array}$ \\
\hline VKT3 & Proses belanja yang mudah tanpa harus pergi keluar rumah \\
\hline VKT4 & $\begin{array}{l}\text { Tampilan Aplikasi Toko Online User Friendly (Mudah dan } \\
\text { Nyaman) }\end{array}$ \\
\hline VKT5 & $\begin{array}{l}\text { Tersedia fasilitas pencarian untuk memudahkan konsumen } \\
\text { dalam menemukan produk yang dibutuhkan }\end{array}$ \\
\hline VKT6 & $\begin{array}{l}\text { Untuk memuat halaman Toko Online tidak membutuhkan } \\
\text { waktu yang lama }\end{array}$ \\
\hline VKT7 & $\begin{array}{l}\text { Pilihan pembayaran sudah cukup banyak untuk memudahkan } \\
\text { konsumen dalam bertansaksi }\end{array}$ \\
\hline VKT8 & $\begin{array}{l}\text { Langkah-langkah bertransaksi menggunakan Toko Online } \\
\text { tergolong mudah }\end{array}$ \\
\hline
\end{tabular}

Tabel 4. Deskripsi Daftar Pertanyaan Responden Untuk Variabel Kemudahan Keamanan Transaksi (VKMT)

\begin{tabular}{|c|l|}
\hline Kode & \multicolumn{1}{|c|}{ Deskripsi Pertanyaan Responden } \\
\hline VKMT1 & $\begin{array}{l}\text { Toko Online memberikan garansi pengembalian barang } \\
\text { dengan syarat tertentu }\end{array}$ \\
\hline VKMT2 & $\begin{array}{l}\text { Toko Online menjamin kerahasiaan data tidak boleh } \\
\text { menyalah gunakan data pribadi konsumen }\end{array}$ \\
\hline VKMT3 & $\begin{array}{l}\text { Toko Online menjamin produk yang sudah dibeli sampai di } \\
\text { tangan konsumen untuk menghindari kejahatan penipuan } \\
\text { dalam transaksi }\end{array}$ \\
\hline VKMT4 & $\begin{array}{l}\text { Toko Online memberikan rasa aman kepada setiap } \\
\text { konsumen sehingga konsumen tidak ragu dalam belanja } \\
\text { Online }\end{array}$ \\
\hline
\end{tabular}


Tabel 5. Deskripsi Daftar Pertanyaan Responden Untuk Variabel Data Kepercayaan

(VK)

\begin{tabular}{|c|l|}
\hline Kode & \multicolumn{1}{|c|}{ Deskripsi Pertanyaan Responden } \\
\hline VK1 & $\begin{array}{l}\text { Saya berbelanja secara Online karena merasa aman dengan } \\
\text { adanya bukti-bukti transaksi yang dicantumkan di situs } \\
\text { tersebut }\end{array}$ \\
\hline VK2 & $\begin{array}{l}\text { Saya berbelanja Online karena kerahasiaan tentang } \\
\text { konsumen belanja Online terlindungi }\end{array}$ \\
\hline VK3 & $\begin{array}{l}\text { Saya berbelanja secara Online karena terdapat jaminan } \\
\text { terkait keamanan dan kerahasiaan }\end{array}$ \\
\hline VK4 & $\begin{array}{l}\text { Saya berbelanja Online karena terdapat kompensasi apabila } \\
\text { tidak sesuai harapan }\end{array}$ \\
\hline
\end{tabular}

Pertanyaan-pertanyaan yang diberikan kepada responden untuk mengukur variabelvariabel, berhubungan diantara variabel yang ada, serta dapat berupa pengalaman dan pendapat dari responden, dengan hasil sebagai berikut:

a) Variabel Harga (VH), Jumlah responden untuk variabel harga Sangat Setuju $(\mathrm{SS})=123$, responden, Setuju $(\mathrm{S})=177$ responden, Netral $(\mathrm{N})=46$ responden, Tidak Setuju $(\mathrm{TS})=4$ responden dan Sangat Tidak Setuju $(\mathrm{STS})=0$ responden .

b) Variabel Produk (VP), Jumlah responden untuk variabel produk Sangat Setuju $(\mathrm{SS})=72$ responden, Setuju $(\mathrm{S})=153$ responden, Netral $(\mathrm{N})=101$ responden, Tidak Setuju $(\mathrm{TS})=23$ responden dan Sangat Tidak Setuju $(\mathrm{STS})=1$ responden.

c) Variabel Kemudahan Transaksi (VKT), Jumlah responden untuk variabel kemudahan transaksi Sangat Setuju (SS)=88 responden, Setuju $(S)=194$ responden, Netral $(\mathrm{N})=59$ responden, Tidak Setuju $(\mathrm{TS})=8$ responden dan Sangat Tidak Setuju $(\mathrm{STS})=1$ responden

d) Variabel Keamanan Transaksi (VKMT), Jumlah responden untuk variabel keamanan transaksi Sangat Setuju (SS)=69 responden, Setuju $(S)=170$ responden, Netral $(N)=96$ responden, Tidak Setuju $(T S)=14$ responden dan Sangat Tidak Setuju $(\mathrm{STS})=1$ responden.

e) Variabel Kepercayaan (VK), Jumlah responden untuk variabel kepercayaan Sangat Setuju $(\mathrm{SS})=49$ responden, Setuju $(\mathrm{S})=143$ responden, Netral $(\mathrm{N})=130$ responden, Tidak Setuju $(\mathrm{TS})=25$ responden dan Sangat Tidak Setuju $(\mathrm{STS})=4$ responden.

Dengan menggunakan persamaan rumus Naïve Bayes Classifier (Alpaydın, 2014) dapat ditulis sebagai berikut:

$$
P(C \mid X)=\frac{P(C \mid X)}{P(X)} \cdot P(C)
$$

\footnotetext{
Keterangan :

$\boldsymbol{x} \quad$ : Data dengan class yang belum diketahui

c : Hipotesis data merupakan suatu class spesifik

$\boldsymbol{P}(\boldsymbol{c} \mid \boldsymbol{x}) \quad$ : Probabilitas hipotesis berdasar kondisi

(posteriori probability)

$\boldsymbol{P}(\boldsymbol{c}) \quad$ : Probabilitas hipotesis (prior probability)

$\boldsymbol{P}(\boldsymbol{x} \mid \boldsymbol{c}) \quad$ : Probabilitas berdasarkan kondisi pada hipotesis

$\boldsymbol{P}(\boldsymbol{x}) \quad$ : Probabilitas c
} 
Pada rumus diatas dapat dijelaskan bahwa teorema Naive Bayes dibutuhkan sebuah petunjuk sebagai proses penentu kelas yang sesuai dengan sampel. Sehingga dibutuhkan kesesuaian terhadap teorema Bayes sebagai berikut:

$$
P(X \mid C)=\frac{P(X \mid C)}{\sum_{i=1}^{n} P\left(C_{i} \mid X\right)} . P(C)
$$

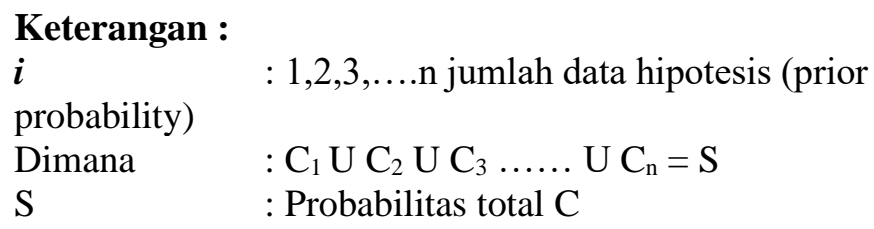

Dengan demikian rumus diatas menjelaskan bahwa peluang masuknya sampel karakteristik tertentu dalam kelas $\mathrm{C}$ (Posterior) merupakan peluang munculnya kelas $\mathrm{C}$ (sebelum adanya sampel) dikalikan peluamg munculnya kriteria sampel pada kelas $\mathrm{C}$ yang kemudian dibagi dengan peluang munculnya kriteria sampel secara keseluruhan, sehingga rumus diatas juga bisa dituliskan sebagai berikut:

$$
\text { Posterior }=\frac{\text { Prior } * \text { likelihood }}{\text { Evidence }}
$$

Dimana nilai evidence selalu tetap pada tiap-tiap kelas dalam sebuah sampel. Sedangkan nilai dari posterior adalah perbandingan nilai antar posterior. Sehingga rumus tersebut dapat dijabarkan sebagai berikut:

$$
\begin{aligned}
P\left(C \mid F_{1}, \ldots F_{n}\right) & =P(C) \cdot P\left(F_{1}, \ldots F_{n} \mid C\right) \\
& =P(C) \cdot P\left(F_{1} \mid C\right) \cdot P\left(F_{2,} \ldots F_{n} \mid C, F_{1}\right) \\
& =P(C) \cdot P\left(F_{1} \mid C\right) \cdot P\left(F_{2,} \mid C, F_{1}\right) \cdot P\left(F_{3,} \ldots F_{n} \mid C, F_{1}, F_{2}\right) \\
=P(C) \cdot P\left(F_{1} \mid C\right) \cdot P\left(F_{2} \mid C,\right. & \left.F_{1}\right) \cdot P\left(F_{3} \mid C, F_{1}, F_{2}\right) \ldots P\left(F_{n} \mid C, F_{1}, F_{2}, F_{3} \ldots F_{n-1}\right)
\end{aligned}
$$

Hasil penjabaran rumus diatas menjelaskan bahwa jika syarat-syarat dalam kelas semakin banyak maka semakin banyak pula nilai probabilitasnya. Hal tersebut sangat tidak memungkinkan jika dilakukan analisis manual satu persatu karena perhitungannya akan semakin sulit, sehingga dapat digunakan rumus sebagai berikut:

$$
P\left(F_{i} \mid F_{j}\right)=\frac{P\left(F_{i} \cap F_{j}\right)}{P\left(F_{j}\right)}=\frac{P\left(F_{i}\right) \cdot P\left(F_{j}\right)}{P\left(F_{j}\right)}=P\left(F_{i}\right)
$$

Persamaan diatas menjelaskan adanya asumsi independen menjadikan syarat dalam sebuah sampel menjadi lebih sederhana dan memungkinkan dihitung dengan rumus yang lebih di sederhanakan sebagai berikut:

$$
P\left(C \mid F_{1}, \ldots F_{n}\right)=\frac{P(C) P\left(F_{1}, \ldots F_{n} \mid C\right)}{P\left(F_{1}, \ldots F_{n}\right)}
$$


Jika diketahui Variabel Harga (VH), Variabel Produk (VP), Variabel Kemudahan Transaksi (VKT), Variabel Keamanan Transaksi (VKMT), dan Kepercayaan memiliki kriteria-kriteria tertentu, sehingga dapat dilakukan penghitungan untuk menentukan $\mathrm{P}$ (Class) sebagai berikut:
a. $\mathrm{P}(\mathrm{Y}=$ Variabel Harga $)$
$=350$
b. $\mathrm{P}(\mathrm{Y}=$ Variabel Produk $)$
$=350$
c. $\mathrm{P}(\mathrm{Y}=$ Variabel Kemudahan Transaksi $)=350$
d. $\mathrm{P}(\mathrm{Y}=$ Variabel Keamanan Transaksi $) \quad=350$
e. $\mathrm{P}(\mathrm{Y}=$ Variabel Kepercayaan $) \quad=350$

\section{HASIL DAN PEMBAHASAN}

Untuk mengetahui hasil perhitungan Class variabel pada Analisa Sentimen Customer Toko Online adalah sebagai berikut:

a) $\mathrm{P}(\mathrm{SS} \mid$ Variabel Harga $=123 / 350) * \mathrm{P}(\mathrm{S} \mid$ Variabel Harga $=177 / 350) * \mathrm{P}(\mathrm{N} \mid$ Variabel Harga $=46 / 350) * \mathrm{P}(\mathrm{TS} \mid$

Variabel Harga $=4 / 350) * \mathrm{P}($ STS $\mid$ Variabel Harga $=$

$0 / 350)$

$=0.352 * 0.505 * 0.131 * 0.010 * 0.001$

$=0.00000023$

b) $\mathrm{P}(\mathrm{SS} \mid$ Variabel Produk $=72 / 350) * \mathrm{P}(\mathrm{S} \mid$ Variabel Produk=153/350) * P $(\mathrm{N} \mid$ Variabel Produk $=101 / 350) * \mathrm{P}(\mathrm{TS} \mid$ Variabel Produk $=23 / 350) * \mathrm{P}(\mathrm{STS} \mid$ Variabel Produk $=1 / 350$ )

$=0.206 * 0.436 * 0.289 * 0.066 * 0.003$

$=0.0000049$

c) $\mathrm{P}(\mathrm{SS} \mid$ Variabel Kemudahan Transaksi $=88 / 350) * \mathrm{P}(\mathrm{S} \mid$ Variabel Kemudahan Transaksi $=194 / 350) * \mathrm{P}(\mathrm{N} \mid$ Variabel Kemudahan Transaksi $=59 / 350) * \mathrm{P}(\mathrm{TS} \mid$ Variabel Kemudahan Transaksi $=8 / 350) * \mathrm{P}(\mathrm{STS} \mid$ Variabel Kemudahan Transaksi $=$ $1 / 350)$

$=0.183 * 0.396 * 0.147 * 0.023 * 0.0200$

$=0.0000048$

d) P (SS | Variabel Keamanan Transaksi $=69 / 350) * \mathrm{P}(\mathrm{S} \mid$ Variabel Keamanan Transaksi $=170 / 350) * \mathrm{P}(\mathrm{N} \mid$ Variabel Keamanan Transaksi $=96 / 350) * \mathrm{P}(\mathrm{TS} \mid$ Variabel Keamanan Transaksi $=14 / 350) * \mathrm{P}($ STS $\mid$ Variabel Keamanan Transaksi $=1 / 350)$

$=0.196 * 0.486 * 0.274 * 0.041 * 0.004$

$=0.0000038$

e) $\mathrm{P}(\mathrm{SS} \mid$ Variabel Kepercayaan $)=49 / 350) * \mathrm{P}(\mathrm{S} \mid$ Variabel Keamanan Kepercayaan $=$ $143 / 350) * \mathrm{P}(\mathrm{N} \mid$ Variabel Keamanan Kepercayaan $=130 / 350) * \mathrm{P}(\mathrm{TS} \mid$ Variabel Keamanan Kepercayaan $=25 / 350) * \mathrm{P}($ STS $\mid$ Variabel Keamanan Kepercayaan $=$ $4 / 350)$

$=0.139 * 0.408 * 0.371 * 0.071 * 0.010$

$=0.000015$

Untuk mengklasifikasikan berdasarkan peluang atau kemungkinan suatu kejadian (probabilitas) dari masing-masing variabel yang mempunyai kemungkian peluang, dengan rincian sebagai berikut:

Tabel 6. Probabilitas Variabel Kriteria Variabel Harga (VH)

\begin{tabular}{|c|c|c|c|c|}
\hline \multicolumn{5}{|c|}{ Nilai Hasil Probabilitas Variabel Harga } \\
\hline $\begin{array}{c}\text { Sangat } \\
\text { Setuju (SS) }\end{array}$ & Setuju (S) & Netral (N) & $\begin{array}{c}\text { Tidak } \\
\text { Setuju (TS) }\end{array}$ & $\begin{array}{c}\text { Sangat Tidak } \\
\text { Setuju (STS) }\end{array}$ \\
\hline $\mathbf{0 . 3 5 2}$ & $\mathbf{0 . 5 0 5}$ & $\mathbf{0 . 1 3 1}$ & $\mathbf{0 . 0 1 0}$ & $\mathbf{0 . 0 0 1}$ \\
\hline
\end{tabular}


Tabel 7. Probabilitas Variabel Kriteria Variabel Produk (VP)

\begin{tabular}{|c|c|c|c|c|}
\hline \multicolumn{5}{|c|}{ Nilai Hasil Probabilitas Variabel Produk } \\
\hline $\begin{array}{c}\text { Sangat } \\
\text { Setuju (SS) }\end{array}$ & Setuju (S) & Netral (N) & $\begin{array}{c}\text { Tidak } \\
\text { Setuju (TS) }\end{array}$ & $\begin{array}{c}\text { Sangat Tidak } \\
\text { Setuju (STS) }\end{array}$ \\
\hline $\mathbf{0 . 2 0 6}$ & $\mathbf{0 . 4 3 6}$ & $\mathbf{0 . 2 8 9}$ & $\mathbf{0 . 0 6 6}$ & $\mathbf{0 . 0 0 3}$ \\
\hline
\end{tabular}

Tabel 8. Probabilitas Variabel Kriteria Variabel Kemudahan Transaksi (VKT)

\begin{tabular}{|c|c|c|c|c|}
\hline \multicolumn{5}{|c|}{ Nilai Hasil Probabilitas Variabel Kemudahan Transaksi } \\
\hline $\begin{array}{c}\text { Sangat } \\
\text { Setuju (SS) }\end{array}$ & Setuju (S) & Netral (N) & $\begin{array}{c}\text { Tidak } \\
\text { Setuju (TS) }\end{array}$ & $\begin{array}{c}\text { Sangat Tidak } \\
\text { Setuju (STS) }\end{array}$ \\
\hline $\mathbf{0 . 2 5 1}$ & $\mathbf{0 . 5 5 4}$ & $\mathbf{0 . 1 6 9}$ & $\mathbf{0 . 0 2 3}$ & $\mathbf{0 . 0 0 3}$ \\
\hline
\end{tabular}

Tabel 9. Probabilitas Variabel Kriteria Variabel Keamanan Transaksi (VKMT)

\begin{tabular}{|c|c|c|c|c|}
\hline \multicolumn{4}{|c|}{ Nilai Hasil Probabilitas Variabel Keamanan Transaksi } \\
\hline $\begin{array}{c}\text { Sangat } \\
\text { Setuju (SS) }\end{array}$ & Setuju (S) & Netral (N) & $\begin{array}{c}\text { Tidak } \\
\text { Setuju (TS) }\end{array}$ & $\begin{array}{c}\text { Sangat Tidak } \\
\text { Setuju (STS) }\end{array}$ \\
\hline $\mathbf{0 . 1 9 6}$ & $\mathbf{0 . 4 8 6}$ & $\mathbf{0 . 2 7 4}$ & $\mathbf{0 . 0 4 1}$ & $\mathbf{0 . 0 0 4}$ \\
\hline
\end{tabular}

Tabel 10. Probabilitas Variabel Kriteria Variabel Kepercayaan (VK)

\begin{tabular}{|c|c|c|c|c|}
\hline \multicolumn{4}{|c|}{ Nilai Hasil Probabilitas Variabel Kepercayaan } \\
\hline $\begin{array}{c}\text { Sangat } \\
\text { Setuju (SS) }\end{array}$ & Setuju (S) & Netral (N) & $\begin{array}{c}\text { Tidak } \\
\text { Setuju (TS) }\end{array}$ & $\begin{array}{c}\text { Sangat Tidak } \\
\text { Setuju (STS) }\end{array}$ \\
\hline $\mathbf{0 . 1 3 9}$ & $\mathbf{0 . 4 0 8}$ & $\mathbf{0 . 3 7 1}$ & $\mathbf{0 . 0 7 1}$ & $\mathbf{0 . 0 1 0}$ \\
\hline
\end{tabular}

Hasil analisis sentimen customer toko online dengan menggunakan probabilitas, sebagai berikut:

1) Hasil Analisis Sentimen Variabel Harga (VH), hasil analisis sentimen customer toko Online berdasarkan variabel harga adalah sebagai berikut:

a) $\mathrm{VH} 1=$ untuk Katalog harga produk jelas ditampilkan dan dimengerti konsumen (Daftar Harga) sebesar 85.49\%, hasil sentimen customer adalah POSITIF

b) $\mathrm{VH} 2=$ Potongan harga yang diberikan toko Online mempengaruhi minat beli konsumen untuk belanja secara Online (Diskon) sebesar 88.63\%, hasil sentimen customer adalah POSITIF

c) $\mathrm{VH} 3=$ Banyaknya promosi yang dilakukan oleh toko Online seperti potongan harga pada hari tertentu, beli 1 gratis 1 , cuci gudang dan lainnya menjadi daya tarik untuk berbelanja secara Online sebesar $86.57 \%$, hasil sentimen customer adalah POSITIF

d) $\mathrm{H} 4=$ Harga Produk toko Online lebih murah sebesar $77.59 \%$, hasil sentimen customer adalah POSITIF

e) VH5=Konsumen sangat mudah melakukan perbandingan harga sebesar $82.91 \%$, hasil sentimen customer adalah POSITIF

f) $\mathrm{VH6}=$ Konsumen dapat menyesuaikan pilihan harga dengan pendapatan masingmasing sebesar $82.51 \%$, hasil sentimen customer adalah POSITIF

Sedangkan total responden secara umum untuk Variabel Harga $(\mathrm{VH})$ sebesar $83.93 \%$, hasil sentimen customer adalah POSITIF, seperti pada grafik dibawah ini 


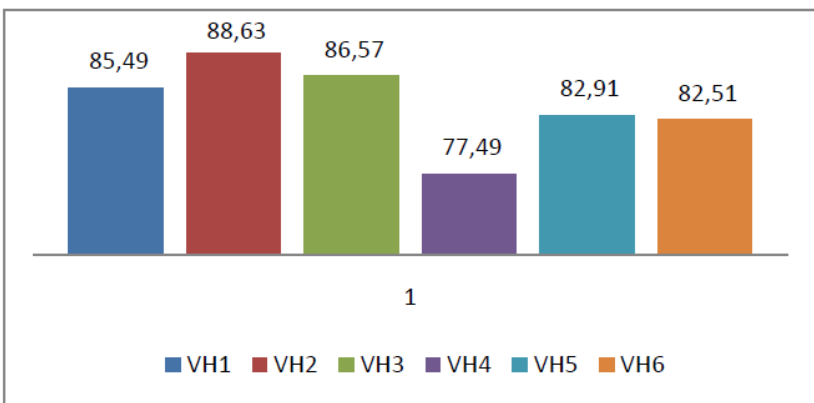

Gambar 1. Hasil Analisis Sentimen Variabel Harga (VH)

2) Hasil Analisis Sentimen Variabel Produk (VP), hasil analisis sentimen customer toko Online berdasarkan variabel produk adalah sebagai berikut:

a) VP1=untuk Banyaknya pilihan yang dijual toko Online sehingga memudahkan konsumen dalam mencari produk yg di inginkan sebesar $85.89 \%$, hasil sentimen customer adalah POSITIF

b) VP2= Produk yg dijual toko Online memiliki kualitas yang lebih baik sebesar $62.34 \%$, hasil sentimen customer adalah POSITIF

c) $\mathrm{VP} 3=$ Toko Online Memberikan pelayanan tambahan untuk menghindari kerusakan ketika pengiriman yaitu memberikan kemasan tambahan pada setiap produk yang dibeli sebesar $76.91 \%$, hasil sentimen customer adalah POSITIF

d) VP4= Merek produk apapun bisa didapatkan dengan belanja online sebesar $77.03 \%$, hasil sentimen customer adalah POSITIF

Sedangkan total responden secara umum untuk Variabel Produk (VP) sebesar 75.54\%, hasil sentimen customer adalah POSITIF, seperti pada grafik dibawah ini

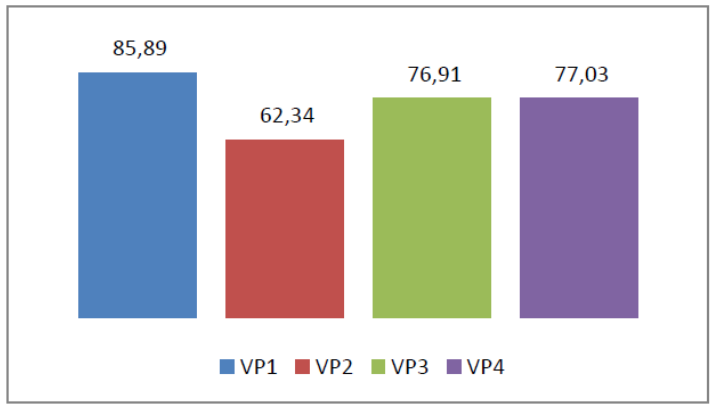

Gambar 2. Hasil Analisis Sentimen Variabel Produk (VP)

3) Hasil Analisis Sentimen Variabel Kemudahan Transaksi (VKT), hasil analisis sentimen customer toko Online berdasarkan variabel kemudahan transaksi adalah sebagai berikut:

a) $\mathrm{VKT} 1=$ untuk Memiliki respon yang cepat ketika melayani pembeli sebesar $72.11 \%$, hasil sentimen customer adalah POSITIF

b) VKT2 $=$ Toko Online selalu menerima pesanan produk dari konsumen selama 24 jam sebesar $75.71 \%$, hasil sentimen customer adalah POSITIF

c) VKT3= Proses belanja yang mudah tanpa harus pergi keluar rumah sebesar $86.74 \%$, hasil sentimen customer adalah POSITIF

d) VKT4= Tampilan Aplikasi Toko Online User Friendly (Mudah dan Nyaman) sebesar $80.00 \%$, hasil sentimen customer adalah POSITIF 
e) VKT5= Tersedia fasilitas pencarian untuk memudahkan konsumen dalam menemukan produk yang dibutuhka sebesar $86.17 \%$, hasil sentimen customer adalah POSITIF

f) VKT6= Untuk memuat halaman Toko Online tidak membutuhkan waktu yang lama sebesar $76.69 \%$, hasil sentimen customer adalah POSITIF

g) VKT7= Pilihan pembayaran sudah cukup banyak untuk memudahkan konsumen dalam bertransaksi sebesar $84.57 \%$, hasil sentimen customer adalah POSITIF

h) $\mathrm{VKT} 8=$ Langkah-langkah bertransaksi menggunakan Toko Online tergolong mudah sebesar $82.57 \%$, hasil sentimen customer adalah POSITIF

Sedangkan total responden secara umum untuk Variabel Kemudahan Transaksi (VKT) sebesar $80.57 \%$, hasil sentiment customer adalah POSITIF, seperti pada grafik dibawah ini.

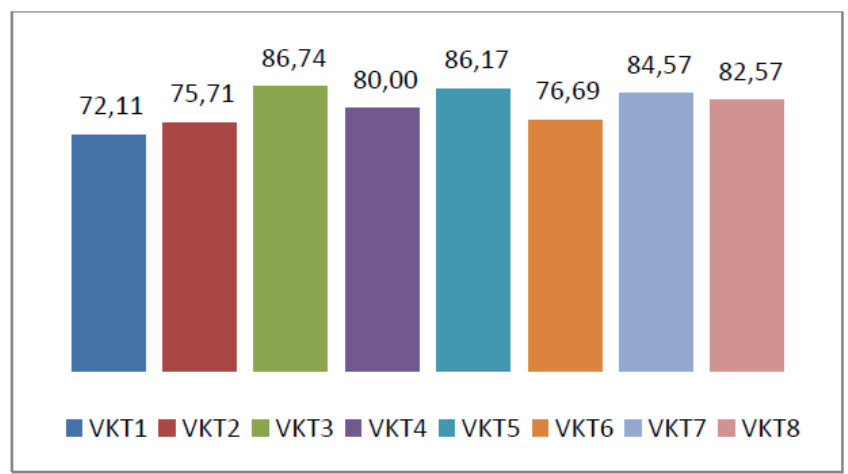

Gambar 3. Hasil Analisis Sentimen Variabel Kemudahan Transaksi (VKT)

4) Hasil Analisis Sentimen Variabel Keamanan Transaksi (VKMT), hasil analisis sentimen customer toko Online berdasarkan variabel keamanan transaksi adalah sebagai berikut:

a) VKMT1= untuk Toko Online memberikan garansi pengembalian barang dengan syarat tertentu sebesar $77.31 \%$, hasil sentimen customer adalah POSITIF

b) VKMT2= Toko Online menjamin kerahasiaan data tidak boleh menyalahgunakan data pribadi konsumen sebesar $76.11 \%$, hasil sentimen customer adalah POSITIF

c) VKMT3= Toko Online menjamin produk yang sudah dibeli sampai di tangan konsumen untuk menghindari kejahatan penipuan dalam transaksi sebesar $77.89 \%$, hasil sentimen customer adalah POSITIF

d) VKMT4= Toko Online memberikan rasa aman kepada setiap konsumen sehingga konsumen tidak ragu dalam belanja Online sebesar 75.14\%, hasil sentimen customer adalah POSITIF

Sedangkan total responden secara umum untuk Variabel Keamanan Transaksi (VKMT) sebesar $76.61 \%$, hasil sentiment customer adalah POSITIF, seperti pada grafik dibawah ini. 


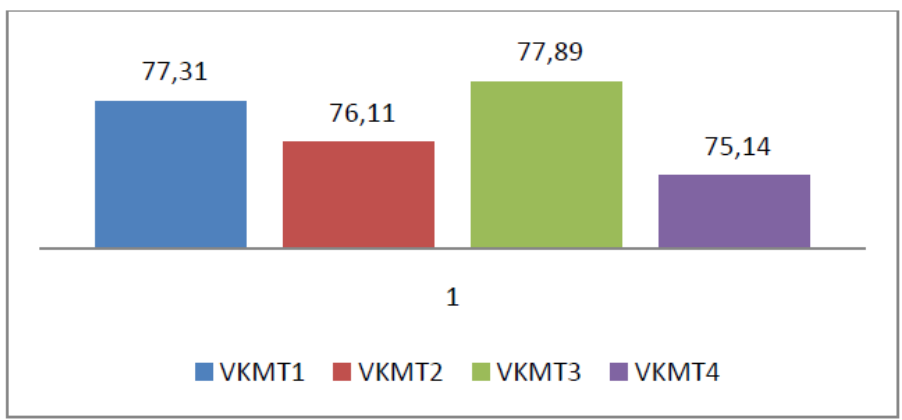

Gambar 4. Hasil Analisis Sentimen Variabel Keamanan Transaksi (VKMT)

5) Hasil Analisis Sentimen Variabel Kepercayaan (VK), hasil analisis sentimen customer toko Online berdasarkan variabel keamanan transaksi adalah sebagai berikut:

a) VK1= untuk Saya berbelanja secara Online karena merasa aman dengan adanya bukti-bukti transaksi yang dicantumkan di situs tersebut sebesar $76.51 \%$, hasil sentimen customer adalah POSITIF

b) $\mathrm{VK} 2=$ Saya berbelanja Online karena kerahasiaan tentang konsumen belanja Online terlindungi sebesar $72.51 \%$, hasil sentimen customer adalah POSITIF

c) $\mathrm{VK} 3=$ Saya berbelanja secara Online karena terdapat jaminan terkait keamanan dan kerahasiaan sebesar $72.29 \%$, hasi sentimen customer adalah POSITIF

d) VK4= Saya berbelanja Online karena terdapat kompensasi apabila tidak sesuai harapan sebesar $66.29 \%$, hasil sentimer customer adalah POSITIF

Sedangkan total responden secara umum untuk Variabel Kepercayaan (VK) sebesar $71.90 \%$, hasil sentimen customer adalah POSITIF, seperti pada grafik dibawah ini.

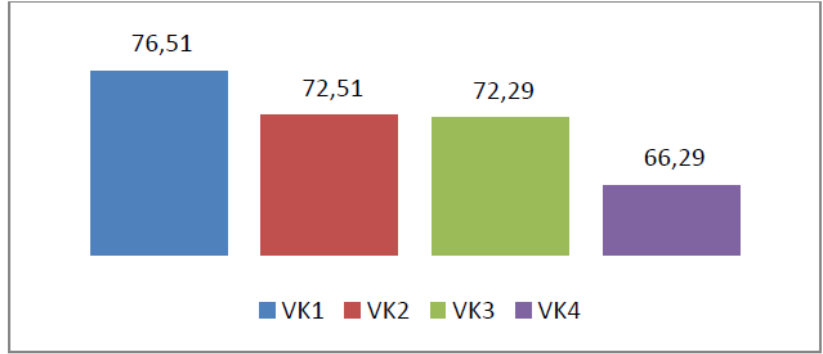

Gambar 5. Hasil Analisis Sentimen Variabel Kepercayaan (VK)

\section{PENUTUP}

Simpulan

Simpulan dalam penelelitian ini adalah sebagai berikut:

a) Untuk Variabel Harga (VH) nilai persepsi sentimen masyarakat dari hasil survei dan perhitungan menggunakan algoritma NBC adalah sebesar 0.00000023, untuk indikator $\mathrm{VH} 1=$ Katalog harg produk jelas ditampilkan dan dimengerti konsumen (Daftar Harga) memiliki kriteria Sangat Setuju dengan hasil 85.49\%, VH2= Potongan harga yang diberikan toko Online mempengaruhi minat beli konsumen untuk belanja secara Online (Diskon) memiliki kriteria Sangat Setuju dengan hasil 88.63\%, VH3= Banyaknya promosi yang dilakukan oleh toko Online seperti potongan harga pada hari tertentu, beli 1 gratis 1 , cuci gudang dan lainnya menjadi daya tarik untuk berbelanja secara Online memiliki kriteria Sangat Setuju dengan hasil 86.57\%, VH4= 
Harga Produk toko Online lebih murah memiliki kriteria Setuju dengan hasil 77.49\%, VH5 = Konsumen sangat mudah melakukan perbandingan harga meiliki kriteria Sangat Setuju dengan hasil $82.91 \%$, VH6= Konsumen dapat menyesuaikan pilihan harga dengan pendapatan masingmasing memiliki kriteria Sangat Setuju dengan hasil $82.51 \%$, dan total hasil dari perhitungan menggunakan tabel Likert untuk persepsi masyarakat terhadap Variabel Harga adalah sebesar $83.93 \%$ dan termasuk dalam kategori POSITIF.

b) Untuk Variabel Produk (VP) nilai persepsi sentimen masyarakat dari hasil survei dan perhitungan menggunakan algoritma NBC adalah sebesar 0.0000049, untuk indikator VP1= Banyaknya pilihan yang dijual toko Online sehingga memudahkan konsumen dalam mencari produk yg di inginkan memiliki kriteria Sangat Setuju dengan hasil $85.89 \%$, VP2= Produk yg dijual toko Online memiliki kualitas yang lebih baik memiliki kriteria Setuju dengan hasil $62.34 \%$, VP3= Toko Online Memberikan pelayanan tambahan untuk menghindari kerusakan ketika pengiriman yaitu memberikan kemasan tambahan pada setiap produk yang dibeli memiliki kriteria Setuju dengan hasil $76.91 \%$, VP4= Merek produk apapun bisa didapatkan dengan belanja Online memiliki kriteria Setuju dengan hasil $77.03 \%$, dan total hasil dari perhitungan menggunakan tabel Likert untuk persepsi masyarakat terhadap Variabel Produk adalah sebesar $75.54 \%$ dan termasu dalam kategori POSITIF.

c) Untuk Variabel Kemudahan Transaksi (VKT) nilai persepsi sentimen masyarakat dari hasil survei dan perhitungan menggunakan algoritma $\mathrm{NBC}$ adalah sebesar 0.0000013 , VKT1=Memiliki respon yang cepat ketika melayani pembeli memiliki kriteria Setuju dengan hasil $72.11 \%$, VKT2= Toko Online selalu menerima pesanan produk dari konsumen selama 24 jam memiliki kriteria Setuju dengan hasil $75.71 \%$, VKT3= Proses belanja yang mudah tanpa harus pergi keluar rumah memiliki kriteria Sangat Setuju dengan hasil 86.74\%, VKT4= Tampilan Aplikasi Toko Online User Friendly (Mudah dan Nyaman) memiliki kriteria Sangat Setuju 80.00\%, VKT5= Tersedia fasilitas pencarian untuk memudahkan konsumen dalam menemukan produk yang dibutuhkan pembeli memiliki kriteria Sangat Setuju dengan hasil 86.17\%, VKT6= Untuk memuat halaman Toko Online tidak membutuhkan waktu yang lama pembeli memiliki kriteria Setuju dengan hasil $76.69 \%$, VKT7= Pilihan pembayaran sudah cukup banyak untuk memudahkan konsumen dalam bertransaksi pembeli memiliki kriteria Sangat Setuju dengan hasil 84.57\%, VKT8=Langkah-langkah bertransaksi menggunakan Toko Online tergolong mudah pembeli memiliki kriteria Sangat Setuju dengan hasil $82.57 \%$, dan total hasil dari perhitungan menggunakan tabel Likert untuk persepsi masyarakat terhadap Variabel Kemudahan Transaksi adalah sebesar $80.57 \%$ dan termasuk dalam kategori POSITIF.

d) Untuk Variabel Keamanan Transaksi (VKMT) nilai persepsi sentimen masyarakat dari hasil survei dan perhitungan menggunakan algoritma NBC adalah sebesar 0.0000038 , VKMT1 $=$ Toko Online memberikan garansi pengembalian barang dengan syarat tertentu memiliki kriteria Setuju dengan hasil 77.31\%, VKMT2= Toko Online menjamin kerahasiaan data tidak boleh menyalahgunakan data pribadi konsumen memiliki kriteria Setuju dengan hasil $76.11 \%$, VKMT3= Toko Online menjamin produk yang sudah dibeli sampai di tangan konsumen untuk menghindari kejahatan penipuan dalam transaksi memiliki kriteria Setuju dengan hasil $77.89 \%$, VKMT4= Toko Online memberikan rasa aman kepada setiap konsumen sehingga konsumen tidak ragu dalam belanja Online memiliki kriteria Setuju dengan hasil $75.14 \%$, dan total hasil dari perhitungan menggunakan tabel Likert untuk persepsi masyarakat terhadap Variabel Keamanan Transaksi adalah sebesar 76.61\% dan termasuk dalam kategori POSITIF. 
e) Untuk Variabel Kepercayaan (VK) nilai persepsi sentimen masyarakat dari hasil survei dan perhitungan menggunakan algoritma NBC adalah sebesar 0.000015, VK1 = untuk Saya berbelanja secara Online karena merasa aman dengan adanya bukti-bukti transaksi yang dicantumkan di situs tersebut memiliki kriteria Setuju dengan hasil $76.51 \%$, VK2= Saya berbelanja Online karena kerahasiaan tentang konsumen belanja Online terlindungi memiliki kriteria Setuju dengan hasil $72.51 \%$, VK3= Saya berbelanja secara Online karena terdapat jaminan terkait keamanan dan kerahasiaan memiliki kriteria Setuju dengan hasil 72.29\%, VK4= Saya berbelanja Online karena terdapat kompensasi apabila tidak sesuai harapan memiliki kriteria Setuju dengan hasil $66.29 \%$, dan total hasil dari perhitungan menggunakan tabel Likert untuk persepsi masyarakat terhadap Variabel Kepercayaan adalah sebesar $80.57 \%$ dan termasuk dalam kategori POSITIF.

\section{DAFTAR PUSTAKA}

Alpaydin, E. (2014). Introduction to Machine Learning Second Edition. In The MIT Press Cambridge, Massachusetts London, England (Vol. 1107). https://doi.org/10.1007/978-162703-748-8_7

Digital in 2019. (2019). Retrieved June 27, 2019, from https://wearesocial.com/global-digitalreport-2019

Find Out E-commerce Competition in Indonesia. (2019). Retrieved June 27, 2019, from https://iprice.co.id/insights/mapofecommerce/en/

Nurhuda, F., Widya Sihwi, S., \& Doewes, A. (2016). Analisis Sentimen Masyarakat terhadap Calon Presiden Indonesia 2014 berdasarkan Opini dari Twitter Menggunakan Metode Naive Bayes Classifier. Jurnal Teknologi \& Informasi ITSmart, 2(2), 35. https://doi.org/10.20961/its.v2i2.630

Setyawan, D., \& Winarko, E. (2016). Analisis Opini Terhadap Fitur Smartphone Pada Ulasan Website Berbahasa Indonesia. IJCCS (Indonesian Journal of Computing and Cybernetics Systems), 10(2), 183. https://doi.org/10.22146/ijccs.17485

Sugiyono. (2014). Metode Penelitian Pendidikan Pendekatan Kuantitatif, Kualitatif dan $R \& D$ (19th ed.). Bandung: Alfabeta.

Wan, Y., \& Gao, Q. (2015). An Ensemble Sentiment Classification System of Twitter Data for Airline Services Analysis. ICDMW'15 Proceedings of the 2015 IEEE International Conference on Data Mining Workshop (ICDMW), (November 14-17, 2015), 1318-1325. 